\title{
Communities' perceptions of benefit-sharing mechanisms for Forest-Based Land Reform Models in South Africa
}

\author{
${ }^{1 *}$ Tshidzumba R.P., ${ }^{1}$ Chirwa, P.W. and ${ }^{1,2}$ Babalola, F.D. \\ ${ }^{1}$ Forest Science Postgraduate Programme, Department of Plant Production and Soil Science, \\ University of Pretoria, South Africa \\ ${ }^{2}$ Forest Resources Management, University of Ilorin, Nigeria
}

\begin{abstract}
One of the dominant challenges facing the South African forestry sector is the issue of land restitution. The aim of this study was, therefore, to assess the perception of beneficiaries of benefit-sharing modalities for forest-based land reform initiatives in their locality. A random sampling technique selected 140 and 175 households in Ama-Bomvini and Cata communities in Kwazulu Natal and Eastern Cape Provinces, respectively. The household beneficiaries have shown a lack of knowledge of the criteria used for the disbursement of the benefits. In addition, over $70.0 \%$ of household beneficiaries in Ama-Bomvini, compared to far less than $70.0 \%$ in Cata, preferred using rental income for infrastructure development in their respective communities. The results further showed that the relationship between the responses of the respondents from both Ama-Bomvini and Cata communities regarding their perception on the existence of the criteria established to share the benefits, was statistically significant $\left(\chi^{2}=34.452, \mathrm{df}=4, \mathrm{p}<0.005\right)$. However, a lack of transparency, trust and greed were among the factors that household beneficiaries identified as the root causes to the poor benefit-sharing mechanisms. Therefore, it is recommended that there should be political will and commitment from government in order to ensure the development and strengthening of existing benefit-sharing policies for the improvement of livelihoods of the land beneficiaries.
\end{abstract}

Keywords: Benefit-sharing, Land Reform, Community Trust, Community Property Association 


\section{Introduction}

The South African forestry sector plays a significant role in rural economic development (Clarke and Foy 1997, Dlomo and Pitcher 2003, Mabece 2016, Anon 2017). The strategic role of the forestry sector in sustainable rapid rural development has been widely acknowledged in various national and sectoral policy documents and plans (ANC 2012). This includes the South Africa National Development Plan-Vision 2030, the accelerated and shared growth initiative for South Africa, and the long-term adaptation scenario for South Africa (National Planning Commission 2013). However, the growth and sustainability of the forestry sector is plagued by many challenges (Makana 2012), such as the issue of land restitution, which is a dominant social challenge (Mzinyane 2011). This was born out of a need to address the injustices of the past where a vast majority of the black population were stripped of their land during apartheid (Clarke 2007, Lahiff et al. 2008, Lahiff et al. 2012). The land restitution programme in the forestry sector has been implemented using various negotiated business-oriented settlement initiatives of government, the claimants and the industry (Mayers and Vermeulen 2002, Nemaangani 2011). The strategic issues of concern in the land restitution programme in the forestry sector are: 1) how to ensure the continuity of forestry enterprises on afforested lands transferred to claimant communities, and 2) how to ensure sustainability and financial viability of forestry enterprises transferred to claimant communities (Forestry South Africa 2015). Hence the growing interest of stakeholders, both government and non-governmental agencies, in assessing the performance of forestland businesses that have been transferred back to claimant communities (Deininger and May 2000).

Many studies conducted in this regard have reported mixed performances of these businesses transferred to claimant communities both in terms of productivity (Van Loggerenberg and Mandondo 2008) and delivery of benefits to communal beneficiaries (Cotula and Leonard 2010, Makhathini 2010, Davis and Lahiff 2011). Furthermore, some of these studies associated the poor performance of transferred forestland businesses to a lack of mutuality in agreements made between land beneficiaries and the private sector (Nawir and Santoso 2005, Cotula and Leonard 2010). A few others have linked the poor performance of these forestland businesses to a lack of decisive post-settlement support from government (Hall 2011) and unequal bargaining power amongst land claimant beneficiaries and private partners (Cundill et al. 2013). In the same vein, some studies reported the challenge of limited 
and/or unclear benefit-sharing mechanisms in the management of transferred forestland businesses (Nawir and Santoso 2005, Lahiff 2007, Otsuka 2007, Romano and Reeb 2008, Davis and Lahiff 2011).

The objective of this study was to assess the perceptions of community beneficiaries on benefit-sharing mechanisms for forest-based land reform (FBLR) initiatives in their locality. To answer this objective, the following research questions were asked: 1) Are the communities satisfied with the current arrangement on income generating approaches for the implemented FBLR initiative?, 2) Are the communities satisfied with the benefit-sharing mechanisms of the FBLR initiative?, 3) Are there concerns communities have with respect to benefit-sharing mechanisms from FBLR models? and 4) What do people believe needs to be done so as to improve equity in benefit-sharing in their communities?

\section{Research Methodology}

\subsection{Description of the study areas}

The study was conducted in the Ama-Bomvini community situated in the Kranskop area in Kwa-Zulu-Natal (KZN) Province and the Cata community situated in the Keiskammahoek (along the Amathole mountain range) area in the Eastern Cape Province (Figure 1). These two communities were beneficiaries of the land transferred through restitution of the Land Rights Act, No. 22 of 1994. Furthermore, the two communities reclaimed their land within the framework of two distinct FBLR models. The Ama-Bomvini community operates the Sales and Leaseback (SLB) model while the Cata community operated the Community Managed Enterprise (CME) model (coordinated through a non-governmental organization (NGO)) for a period of more than five years. The Ama-Bomvini community received their land back in the year 2008, and subsequently reached an agreement to lease back the land to one of the private forestry companies for two 20-year rotations under the leadership of the community established Trust (Table 1). 


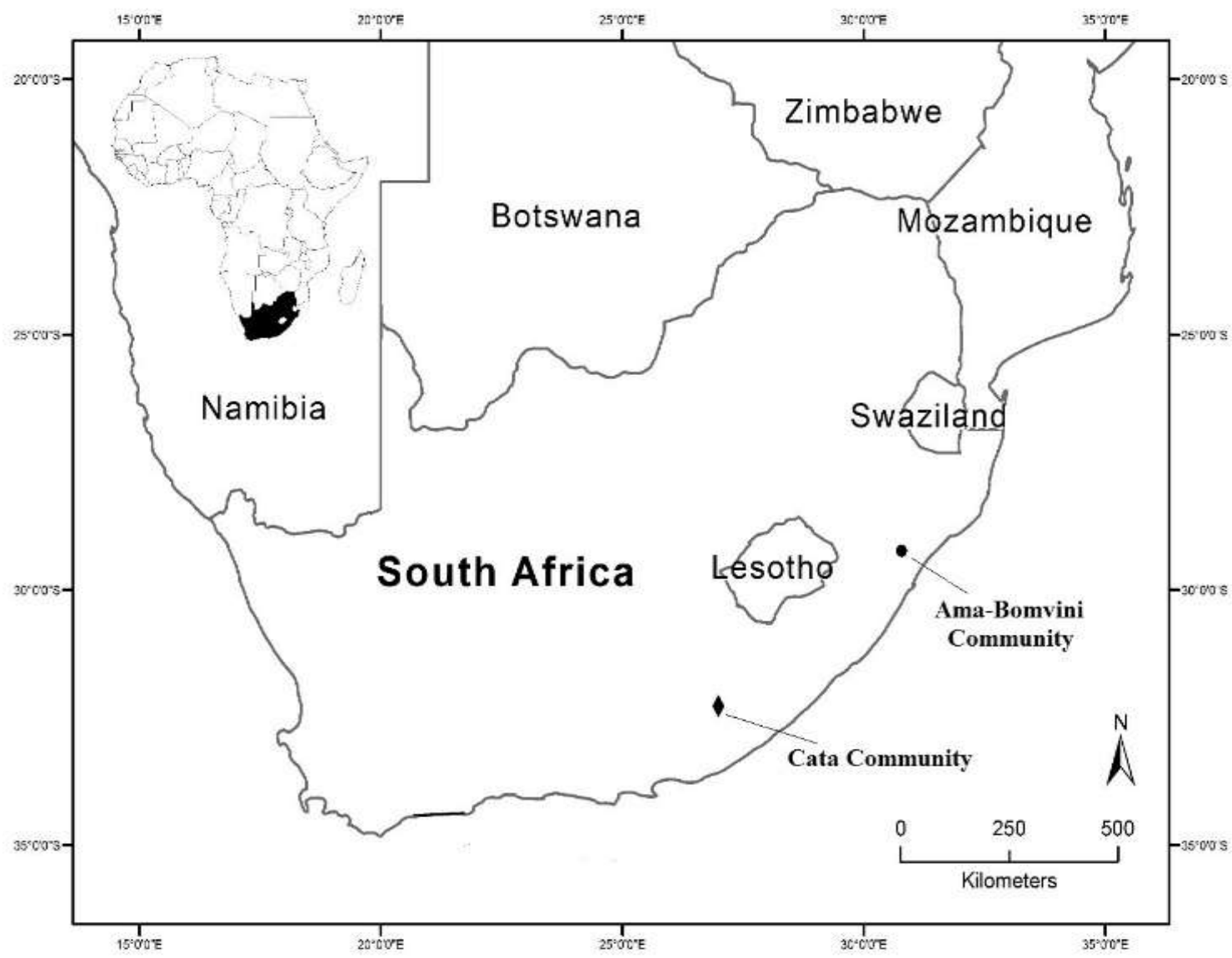

Figure 1: The South African map depicting the study areas in selected provinces

The Ama-Bomvini (Eyethu) Community Trust (CT) registered a company that was named Ingudle. As part of the sales and leaseback agreement between the Community Trust and the partnering company, Ingudle Company was contracted to manage all silvicultural operations in the plantation with mentorship provided by the partnering forest company. The Cata community received their land back in 2002, and subsequently opted to pursue the management of the land by themselves under the leadership of a Trust, which later was changed into a Community Property Association (CPA). However, the Cata community works closely with the Border Rural Committee (BRC), which is an NGO that provides mentorship and sources funding. 
Table 1: Description of the selected communities profile

\begin{tabular}{|c|c|c|}
\hline Information & Ama-Bomvini & Cata \\
\hline Land claim settlement & 2008 & 2002 \\
\hline Commencement of partnership & 2008 & 2002 \\
\hline Partner type & Private company & NGO \\
\hline Duration of the agreement & 20 years & Not specified \\
\hline Forest-based land reform model adopted & SLB & $\mathrm{CME}$ \\
\hline Registered Entity & Community Trust & CPA \\
\hline Province & Kwa-Zulu Natal & Eastern Cape \\
\hline Municipality & Umvoti & Amahlati \\
\hline Language & Zulu & Xhosa \\
\hline Locality & Rural & Rural \\
\hline \multirow[t]{2}{*}{ Geographic location } & $29^{\circ} 5 ’ 26.38^{\prime \prime} \mathrm{S}$ & $32^{\circ} 35^{\prime} 20.90 ’ \mathrm{~S}$ \\
\hline & $30^{\circ} 56^{\prime} 48.22^{\prime \prime} \mathrm{E}$ & $27^{\circ} 7^{\prime} 19.46^{\prime \prime} \mathrm{E}$ \\
\hline Number of Household beneficiaries & 220 & 320 \\
\hline Size of the claimed land & 2038 ha & 650 ha \\
\hline Size of the land leased back & 1515 ha & 0 ha \\
\hline Registered company & Ingudle & None \\
\hline Household respondent's profile & \multicolumn{2}{|c|}{$\begin{array}{l}\text { Proportion of respondents }(\%) \text { in two } \\
\text { communities }\end{array}$} \\
\hline \multicolumn{3}{|c|}{ 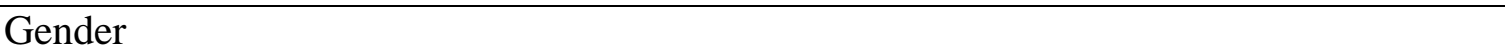 } \\
\hline Male & 41.4 & 36.6 \\
\hline Female & 58.6 & 63.4 \\
\hline \multicolumn{3}{|l|}{ Age category } \\
\hline $18-35$ & 11.4 & 7.4 \\
\hline $36-55$ & 34.3 & 24 \\
\hline Over 55 & 54.3 & 68.6 \\
\hline \multicolumn{3}{|l|}{ Higest level of education } \\
\hline Not educated & 33.6 & 14.9 \\
\hline Primary & 45.7 & 46.3 \\
\hline Secondary & 20.0 & 36.0 \\
\hline Tertiary & 0.7 & 2.9 \\
\hline \multicolumn{3}{|l|}{ Marital status } \\
\hline Single & 44.3 & 19.4 \\
\hline Married & 42.9 & 52.6 \\
\hline Divorce & 0.7 & 8.6 \\
\hline Widow/widower & 12.1 & 19.4 \\
\hline
\end{tabular}

\subsection{Sampling and data collection}

In this study, a mixed-mode research design approach was used (Bhattacherjee, 2012). The choice of this approach was mainly to ensure that all responses were represented (Kelley et al. 2003), additionally, probability sampling was chosen to avoid sampling biases. Specifically, simple random sampling was used in both selected areas (Onwuegbuzie and 
Collins 2007), while the sampling size determination was adopted from Krejcie and Morgan (1970). Accordingly, beneficiaries from 140 heads of households were randomly sampled in the Ama-Bomvini community and 175 in the Cata community. The total number of household beneficiaries, as captured in the beneficiaries' register in each community, was used at a $95 \%$ confidence level and a 5\% confidence interval to determine the sample size required for the household surveys. In addition, considering that the total population or number of household beneficiaries was known, the following formula was used:

$$
\mathrm{S}=\frac{X^{2} N P(1-P)}{d^{2}(N-1)+X^{2} P(1-P)}
$$

Where:

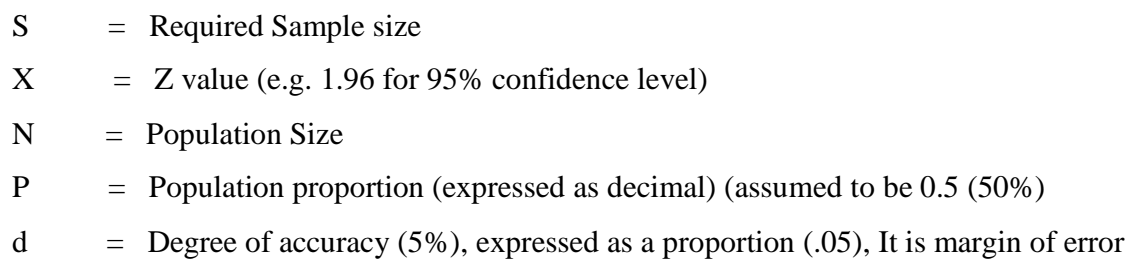

To identify the households that were to be interviewed, randomization was conducted using the beneficiaries register list provided by the Trust in the Ama-Bomvini community and the CPA in the Cata community. This was intended to make sure that the households that participated in the survey actually represented the beneficiaries of the land.

\subsection{Focus Group Discussion}

Focus group discussions were conducted with the trustees in Ama-Bomvini, and CPA committee members in Cata respectively, in order to harness beneficiaries' perceptions of the FBLR models (Wong 2008). In each community, the focus group discussions were carried out with six participants (Onwuegbuzie and Collins 2007), with their selection considered due to their in-depth knowledge and understanding on the day-to-day operations of the partnership. The questions posed for the discussion during the focus group ranged from 1) whether participants believed benefit-sharing mechanisms existed or not owing to the FBLR partnership model implemented in their community, and 2) what obstacles affected benefitssharing mechanisms in their community? 


\subsection{Household questionnaire}

Beneficiaries, consisting of household heads in each community (Chirwa et al. 2015), were interviewed using a generic structured questionnaire (Sjetne et al. 2011). The questions explored the type of socioeconomic benefits that household beneficiaries in both communities received due to the FBLR partnership model adopted. The questionnaire was fourteen pages long with 43 individual questions. For maintenance of originality and understanding, as well as ease of administration (Boynton 2004), the questionnaire was translated into both isiZulu for the Ama-Bomvini community and isiXhosa for the Cata community. In line with Nyariki (2009), the local enumerators were used for the administration of the questionnaire as well as for easy identification of households randomly selected. A five point Likert scale was used for most questions in this study. A pre-test of the questionnaire was carried out in the Ama-Hlongwa community in Kwa-Zulu Natal to ensure that the data collection process covered the scope intended for this study (Collins 2003, Mathers et al. 2007, Nyariki 2009).

\subsection{Data Analysis}

The primary data obtained through the questionnaires were coded and analysed using the Statistical Package of Social Science (SPSS), version 20. The results were analysed using both descriptive statistics and inferential analysis. The descriptive statistics included frequencies and percentages, while inferential analysis used the chi-square test of independence (Anon 2012) to test if there was a significant relationship between perceptions of the beneficiaries in Ama-Bomvini and Cata households regarding benefit-sharing criteria in their implemented FBLR model.

\section{Results}

\subsection{Satisfaction with income generating approaches}

The results of respondents' satisfaction with prevailing income generating approaches of the FBLR initiatives adopted by their community are shown in Table 2. The respondents from the Ama-Bomvini (64.7\%) and Cata (57.7\%) communities were strongly satisfied with the 
agreed/prevailing condition of payment per tonnage approach in their community. However, the respondents were only fairly satisfied with stumpage fee payment $(42.0 \%$ and $46.9 \%)$ and market rate payment (44.2\% and 38.3\%) income generating approaches, respectively. Nevertheless, the majority of the sampled households from Ama-Bomvini (80.7\%) and Cata $(65.7 \%)$ strongly agreed that beneficiaries should be actively involved during the setting of the price to be paid to them from the harvested timber from plantations on their transferred land.

Table 2: Opinion of households on income generating approaches from forest-based land reform initiatives in their community

\begin{tabular}{|c|c|c|c|}
\hline \multirow[t]{3}{*}{$\begin{array}{l}\text { Implemented income generating } \\
\text { approach }\end{array}$} & \multirow[t]{3}{*}{ Responses } & \multicolumn{2}{|c|}{$\begin{array}{l}\text { Proportion of Respondents } \\
(\%) \text { in }\end{array}$} \\
\hline & & \multirow{2}{*}{$\begin{array}{c}\text { Ama- } \\
\text { Bomvini } \\
(\mathrm{n}=140)\end{array}$} & \multirow{2}{*}{$\begin{array}{c}\text { Cata } \\
(n=175)\end{array}$} \\
\hline & & & \\
\hline \multirow[t]{5}{*}{ Payment per tonnage harvested } & Strongly Agree & 64.7 & 57.7 \\
\hline & Agree & 20.9 & 22.3 \\
\hline & Neither agree nor disagree & 10.8 & 13.1 \\
\hline & Disagree & 2.2 & 5.7 \\
\hline & Strongly Disagree & 1.4 & 1.1 \\
\hline \multirow[t]{5}{*}{ Stumpage fee payment } & Strongly Agree & 42.0 & 46.9 \\
\hline & Agree & 24.6 & 39.4 \\
\hline & Neither agree nor disagree & 27.5 & 10.3 \\
\hline & Disagree & 3.6 & 2.3 \\
\hline & Strongly Disagree & 2.2 & 1.1 \\
\hline \multirow[t]{5}{*}{ Market rate payment } & Strongly Agree & 44.2 & 38.3 \\
\hline & Agree & 26.8 & 20.6 \\
\hline & Neither agree nor disagree & 14.5 & 20.0 \\
\hline & Disagree & 6.5 & 14.3 \\
\hline & Strongly Disagree & 8.0 & 6.9 \\
\hline \multirow{5}{*}{$\begin{array}{l}\text { Beneficiaries involvement in } \\
\text { setting the price }\end{array}$} & Strongly Agree & 80.7 & 65.7 \\
\hline & Agree & 10.0 & 16.6 \\
\hline & Neither agree nor disagree & 5.0 & 8.6 \\
\hline & Disagree & 2.1 & 6.9 \\
\hline & Strongly Disagree & 2.1 & 2.3 \\
\hline
\end{tabular}

\subsection{Equity in benefit sharing from implemented forest-based land reform initiatives}

The FBLR models designed by the South African forestry industry were intended to provide necessary benefits to household beneficiaries by ensuring active business participation by the 
claimants. The results in Table 3 show the perceptions of the household beneficiaries of the existence of criteria used to share the benefits at Cata and Ama-Bomvini, In the Cata community, $28.0 \%$ of the respondents were strongly of the opinion that the criteria for benefit-sharing existed, compared to only $12.9 \%$ in the Ama-Bomvini community. On the contrary, $56.1 \%$ and $36.6 \%$ of household beneficiaries in Ama-Bomvini and Cata respectively, revealed that there were no benefit-sharing criteria. Interestingly, the results showed that there is no agreement amongst the Cata household respondents regarding the existence of benefit-sharing criteria, and yet, the Cata CPA committee members expressed during the focus group discussion that the main objective for the committee is to create equal benefit-sharing opportunities for all the beneficiaries. Furthermore, the results showed that the relationship between the Ama-Bomvini and Cata communities regarding their perceptions of the existence of the criteria established to share the benefits, were statistically significant $\left(\chi^{2}=34.452, \mathrm{df}=4, \mathrm{p}<0.001\right)$.

Table 3: Perceptions of household beneficiaries of the existence of benefit-sharing criteria

\begin{tabular}{|c|c|c|c|c|c|}
\hline \multirow[t]{2}{*}{ Responses } & \multicolumn{2}{|c|}{$\begin{array}{l}\text { Proportions of } \\
\text { respondents (\%) in }\end{array}$} & \multicolumn{3}{|c|}{ Inferential Statistics } \\
\hline & $\begin{array}{c}\text { Ama- } \\
\text { Bomvini } \\
(\mathrm{n}=140)\end{array}$ & $\begin{array}{c}\text { Cata } \\
(n=175)\end{array}$ & $\chi^{2}$ & Df & P-value \\
\hline Strongly Agree & 12.9 & 28.0 & & & \\
\hline Agree & 3.6 & 13.7 & & & \\
\hline Neither agree nor disagree & 30.7 & 16.0 & 34.452 & 4 & 0.000 \\
\hline Disagree & 0.7 & 5.7 & & & \\
\hline Strongly Disagree & 56.1 & 36.6 & & & \\
\hline
\end{tabular}

\subsection{Concerns with the benefit-sharing mechanisms of adopted forest-based land reform initiatives}

The perceptions of the household respondents of the factors that contributed to the nonexistence of the benefit-sharing mechanisms are shown in Table 4 . A total of $85.2 \%$ of the household respondents from the Cata community, compared to $70.6 \%$ of those from AmaBomvini, indicated that the lack of transparency has caused poor performance of the adopted FBLR model concerning benefits-sharing. The majority of the respondents from AmaBomvini $(86.9 \%)$ perceived the lack of trust amongst beneficiaries as a concern in realizing 
fair distribution of benefits to all, compared to those from Cata (66.4\%). Furthermore, a lack of clear benefit-sharing mechanisms in both communities remained an issue of concern to the beneficiaries. In Cata community, more than $80 \%$ of household respondents expressed greed amongst beneficiaries to serve in the trust or the CPA, a lack of financial and technical management skills as a contributing factor to poor benefit-sharing compared to less than $80 \%$ of the respondents in Ama-Bomvini community. In addition, the results showed that the relationship between the responses of both the respondents from Ama-Bomvini and Cata regarding factors that contributed to poor benefit-sharing was statistically significant at $\mathrm{p}<0.001$.

Table 4: Household perceptions of factors influencing poor performance with respect to benefits-sharing

\begin{tabular}{|c|c|c|c|c|c|c|}
\hline \multirow{3}{*}{$\begin{array}{l}\text { Factors } \\
\text { influencing } \\
\text { benefit sharing }\end{array}$} & \multirow[t]{3}{*}{ Responses } & \multicolumn{2}{|c|}{$\begin{array}{l}\text { Proportions of } \\
\text { respondents }(\%) \text { in }\end{array}$} & \multicolumn{3}{|c|}{ Inferential statistics } \\
\hline & & $\begin{array}{c}\text { Ama- } \\
\text { Bomvini }\end{array}$ & Cata & $\chi^{2}$ & $\mathrm{df}$ & Sig. \\
\hline & & $(n=140)$ & $(n=175)$ & & & \\
\hline \multirow{5}{*}{$\begin{array}{l}\text { Lack of } \\
\text { transparency }\end{array}$} & Strongly Agree & 61.2 & 60.6 & & & \\
\hline & Agree & 9.4 & 24.6 & & & \\
\hline & Neither agree nor disagree & 10.8 & 6.9 & 32.723 & 4 & 0.000 \\
\hline & Disagree & 2.9 & 6.3 & & & \\
\hline & Strongly Disagree & 15.8 & 1.6 & & & \\
\hline \multirow{5}{*}{$\begin{array}{l}\text { Lack of trust } \\
\text { amongst } \\
\text { beneficiaries }\end{array}$} & Strongly Agree & 46.4 & 52.0 & & & \\
\hline & Agree & 20.0 & 34.9 & & & \\
\hline & Neither agree nor disagree & 22.9 & 7.4 & 22.909 & 4 & 0.000 \\
\hline & Disagree & 4.3 & 3.4 & & & \\
\hline & Strongly Disagree & 6.4 & 2.3 & & & \\
\hline \multirow{5}{*}{$\begin{array}{l}\text { Greediness for } \\
\text { power amongst } \\
\text { beneficiaries }\end{array}$} & Strongly Agree & 41.7 & 67.4 & & & \\
\hline & Agree & 16.5 & 22.3 & & & \\
\hline & Neither agree nor disagree & 30.9 & 4.0 & 47.621 & 4 & 0.000 \\
\hline & Disagree & 5.8 & 3.4 & & & \\
\hline & Strongly Disagree & 5.0 & 2.9 & & & \\
\hline \multirow{5}{*}{$\begin{array}{l}\text { Lack of financial } \\
\text { and technical } \\
\text { management skill }\end{array}$} & Strongly Agree & 53.6 & 54.3 & & & \\
\hline & Agree & 18.1 & 30.3 & & & \\
\hline & Neither agree nor disagree & 23.2 & 5.7 & 29.623 & 4 & 0.000 \\
\hline & Disagree & 0.7 & 6.9 & & & \\
\hline & Strongly Disagree & 4.3 & 2.9 & & & \\
\hline \multirow{5}{*}{$\begin{array}{l}\text { Lack of clear } \\
\text { benefits sharing } \\
\text { approach }\end{array}$} & Strongly Agree & 65.0 & 50.3 & & & \\
\hline & Agree & 13.9 & 34.3 & & & \\
\hline & Neither agree nor disagree & 15.3 & 7.4 & 22.472 & 4 & 0.000 \\
\hline & Disagree & 1.5 & 4.6 & & & \\
\hline & Strongly Disagree & 4.4 & 3.4 & & & \\
\hline
\end{tabular}




\subsection{Desired mechanisms for benefit-sharing}

The desired mechanisms of respondents for benefit-sharing for the different FBLR models adopted in each community, are shown in Figure 2. A larger proportion of the household respondents from both communities had equally shared similar sentiments (62.9\% apiece), which highlights the significance of investing FBLR partnership generated income on business development as a tangible benefits-sharing mechanism. Additionally, the household respondents from both communities are of the view that income generated from the FBLR model should be invested towards provisioning of bursary funding for tertiary education. Similarly, the investment of income generated towards youth development was strongly perceived as a vital benefits-sharing mechanism by those in Ama-Bomvini (77.9\%) and Cata $(68.6 \%)$. In the focus group discussion, the Ama-Bomvini trustees highlighted dropping out from education and training programmes by those youth funded with bursaries and limited rental income to address all the beneficiaries' training and other developmental needs as a serious challenge. Furthermore, the results showed that fewer than $40 \%$ of household respondents from the Cata community perceived the building of clinics, roads and community halls as desirable benefit-sharing mechanisms worth investing in, compared to more than $70 \%$ of those from Ama-Bomvini. 


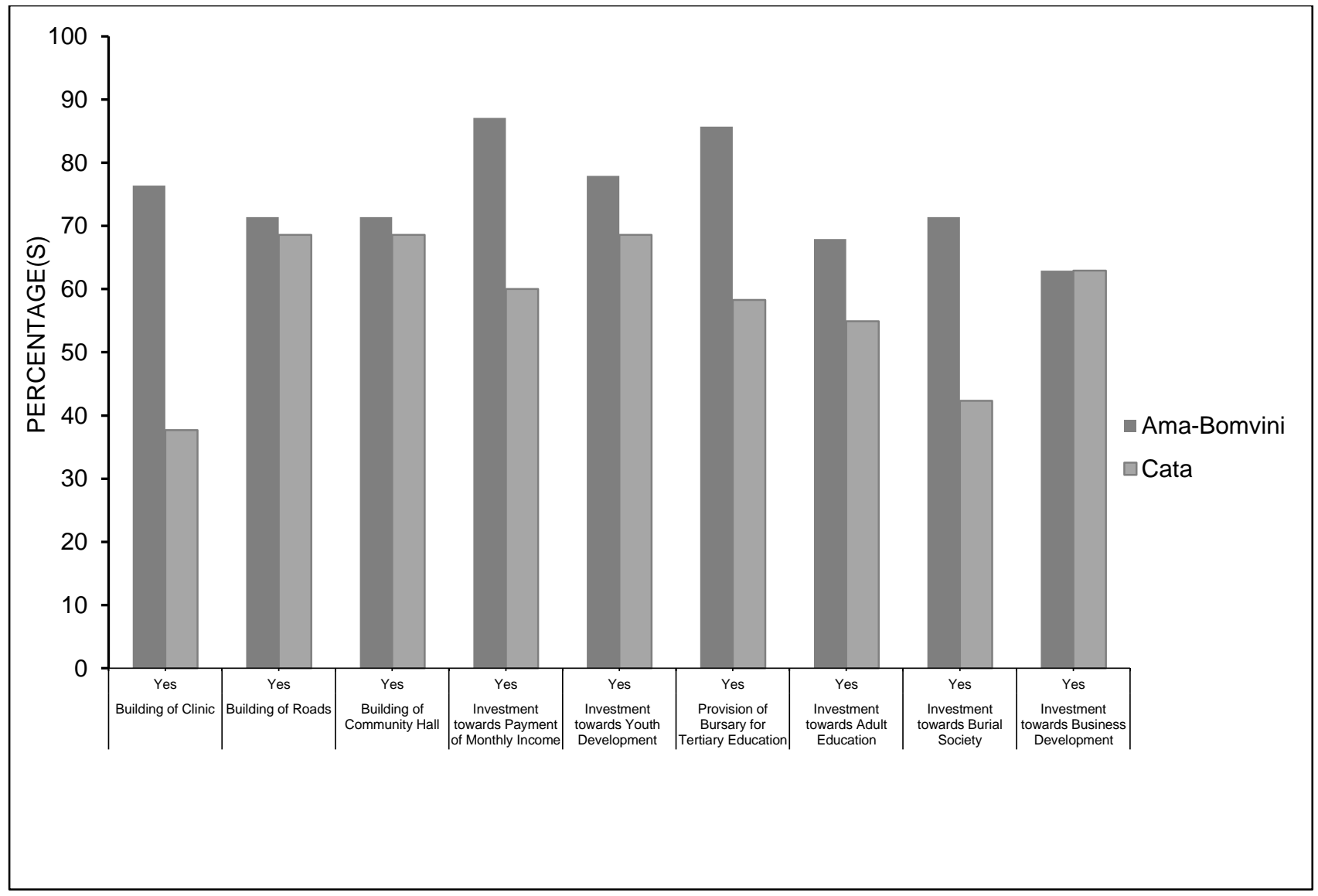

Figure 2: Household beneficiaries' perceptions of benefit-sharing mechanisms from the forest-based land reform model

\section{Discussion}

\subsection{Benefit preferences of community beneficiaries}

The implementation of FBLR models has been highly anticipated to generate income benefits for the beneficiaries. However, the results confirmed that household respondents, from both community beneficiaries selected in this study, supported the income generating approaches set in their respective adopted FBLR partnership model agreements. As noted by Makhathini (2010) the annual income through rental payment to the beneficiaries is made in advance and as such, often resonates well with the beneficiaries. On the other hand, the income sourced through donor funding and other government funding agencies to develop their land reform project has been found to be vital in the Cata community. Furthermore, it is interesting to note that the majority of people from both communities preferred to be involved in the process of setting up the mode of benefits. This simply suggests that land claimant 
beneficiaries have been keen to participate in decision-making from the onset of the partnership agreements on how the income benefits should be distributed to them. In contrast, Morsello (2006) argued that communities usually enjoy less negotiating power during the implementation of public-private partnerships as they are normally approached by companies with predetermined benefits. This in turn adversely affects the objective of community empowerment. In fact, it has been suggested that setting up negotiation procedures through formal contracts could be ideal to improve community participation in the price negotiation process (Mayers and Vermeulen 2002). According to Nawir (2012), the success of local communities in the management of forest enterprises requires strong knowledge of financial management and technical skills as well as a mutual system for benefits- and costs-sharing.

\subsection{Perception of the availability of benefit-sharing mechanisms}

The study showed that both Ama-Bomvini and Cata communities had little knowledge of the existence of the benefit-sharing mechanisms implemented as a result of the adopted FBLR models in their respective communities. However, compared to the Ama-Bomvini community, the Cata community, to a certain extent, perceived that the benefit-sharing mechanisms existed and credited this to the CME model adopted in their community. This perception in the Cata community could be attributed to the fact that the majority of the beneficiaries accessed reasonable benefits in the form of employment from different community projects including forestry, tourism and agriculture. This was echoed from the key informants from the Cata CPA, who stressed that their objective was to ensure benefitsharing of the project to the majority of community beneficiaries. Thus, several supporting community projects, with the assistance of the Border Rural Committee (a non-governmental organization), were established as an approach to create many such alternatives for the benefit of general beneficiaries. The contrast in the perceptions of the household respondents from these two communities could be entirely based on the level of benefits and/or opportunities provisioned by the public-private partnership structure under the different FBLR models. Morsello (2006), however, emphasized that the scarcity of employment opportunities for rural communities deepens the levels of economic uncertainties among households.

In their study, Van Loggerenberg and Mandondo (2008) concluded that equitable benefitsharing mechanisms still require more attention. It has also been argued that more land 
reform projects in South Africa (Hall 2004), and elsewhere in the world, have failed to provide benefits equally to its members (Cernea 2007, Tilley and Lahiff 2007). Likewise, the FBLR public-private partnership models, tailor-made to land claim settlements by individual companies, come with predefined benefits intended for the empowerment of the community beneficiaries (Makhathini 2010). However, the experience on the ground indicates a poor flow of benefits to the majority of the beneficiaries (Davis and Lahiff 2011), while on the other hand, benefits are often enjoyed by the elite few at the expense of the majority of beneficiaries (Mamba 2013, Chirwa et al. 2015).

It was also apparent from the findings that the elite and those who often form part of the trustees or the CPA committee members, embrace the approach in order to benefit themselves at the expense of the majority. To address this, active participation by the government in monitoring and evaluation of the management of CTs and/or CPAs is necessary. In line with this argument, Binswanger-Mkhize (2014) and Sasu (2005) suggest that the development of standard procedures and/or approaches for benefit-sharing are essential in ensuring fair distribution of benefits to all beneficiaries. On the other hand, Cernea (2007) suggests that the political interest of government is important to ensure adherence to benefit-sharing approaches outlined in the public-private partnership agreements. Evidently, outlining different possible standard benefit-sharing mechanisms could be vital to influence the distribution of benefits by CT and/or CPA members. According to Sasu (2005) and Mahanty et al. (2009), issues pertaining to policy and legislative challenges concerning benefit-sharing, and allocation and ownership of resources amongst stakeholders needs to be swiftly resolved.

\subsection{Perceived factors affecting equity benefit-sharing amongst the beneficiaries}

The findings of this study reveal that equitable benefit-sharing among the beneficiaries in both communities has not been highly achieved, with this effect experienced more in AmaBomvini than Cata. Moreover, the difference in the perceptions of the respondents may be associated with the FBLR partnership model adopted in each community. In particular, the respondents from both communities associated the failure to achieve equitable benefitsharing amongst the beneficiaries with a lack of transparency, trust, financial management skills and clearly defined benefit-sharing approaches, as well as excessive greed. Interestingly, this is consistent with what Anseeuw and Mathebula (2008) observed in that the main challenge in land reform projects is generally due to poor governance skills 
demonstrated by CPA committee members and/or Trustees, coupled with a lack of transparency on the use of benefits accumulated from the partnership agreement. On the other hand, both Cairns (2000) and Sasu (2005) found that a lack of clarity on issues of ownership and responsibility had an effect on benefit-sharing amongst the beneficiaries, while at the same time rendering the public-private partnership (PPP) inefficient. In addition, Cousins (2016) and Chirwa et al. (2015) strongly argued that elite capture has often defeated the objective of achieving benefit-sharing amongst land reform beneficiaries. As clearly articulated in the finding of this study, it would be highly significant for the CPA committee members or Trustees to put some measures in place that would allow all the beneficiaries to enjoy the partnership-accumulated benefits equally, irrespective of their positions within the structures of the community.

However, the active participation of both government and/or private partners is imperative in shaping the capacity of CPA committee members and/or Trustees to effectively and efficiently manage the benefits accumulated from the adopted PPP model for the benefit of all the community beneficiaries (Binswanger-Mkize 2014, Cousins 2016). Accordingly, Lahiff (2007) emphasized that little progress has been made to change the livelihoods of the beneficiaries of land reform in South Africa and as such, there is still more that needs to be done to address this daunting situation. Thus, collective efforts between government departments, the forestry industry and/or non-governmental organizations responsible for community development initiatives may prove to be significant in the crafting of clearly defined benefit-sharing mechanisms. As stated by Gwanya (2010), it would also remain critical for the government to consistently provide monitoring and evaluation for the duration of the PPP as that would ensure that the rights of the beneficiaries are respected and protected. Similarly, de Haen and Thompson (2003) strongly suggested that efforts to ensure the improvement of the livelihoods of local communities critically requires political will and a stable commitment towards finding an all-encompassing rural development initiative that delivers noticeable benefits to local people.

\subsection{Desired benefit-sharing modalities by the community beneficiaries}

The findings revealed a noticeable variation regarding the benefit-sharing mechanisms preferred in each community by household beneficiaries. Hence, the difference in the preferences of how the rental or donor money should be used provides an interesting finding 
in that Cata community beneficiaries enjoyed more employment benefits, which, to a certain extent, improved the socioeconomic stability of the household beneficiaries. On the other hand, the preference by Ama-Bomvini households to invest rental money towards tertiary education could be associated with the adopted FBLR model, wherein the beneficiaries' Trust company is employed to carry out silvicultural operations in the plantation. BinswangerMkhize (2014) highlighted the necessity for drastic changes in the design and implementation of land reform projects if their success in delivery of benefits to the beneficiaries is to be realized. In addition, the involvement of the beneficiaries in the determination of the modalities for sharing the benefits attained from their project, may prove vital in ensuring reciprocal beneficiation (Sasu 2005, Hallam 2011).

\section{Conclusion}

The study showed that generally, the CME has potential to empower the household beneficiaries rapidly through active and direct ownership of forestland business compared to the SLB forest-based land reform model. However, a challenge with the model is finding financial resources that can ensure sustainability of the operations in the future in the absence of the support from the NGO. The FBLR models provided certain mechanisms for benefitsharing amongst the beneficiaries in the study communities. The household beneficiaries have shown a lack of knowledge of the criteria used for the disbursement of the benefits. In addition, the majority of the household beneficiaries in both Ama-Bomvini and Cata highlighted their preference for using rental income for infrastructure development in their respective communities. Likewise, the household beneficiaries indicated the need for them to be involved in the setting-up of the benefits, before implementation of the FBLR model. More of the household beneficiaries from Ama-Bomvini, than those from Cata, preferred that the rental money be invested for the provisioning of bursaries for tertiary education, towards burial societies, youth development and adult education. The lack of transparency and trust, as well as excessive greed, were amongst the factors that the household respondents identified as the root causes of the unavailability of benefit-sharing mechanisms in both communities, but this was more prominent in Ama-Bomvini.

This study, therefore, recommends that all stakeholders' inclusive benefit-sharing mechanisms be developed with clear processes and approaches for easy implementation. However, the government would have to take a lead and make sure that monitoring and 
evaluation of the CPAs and CTs is prioritized in order to ensure that the benefits trickle down to all the beneficiaries equitably. Additionally, there is a great need for renewed political will and commitment from government to facilitate the development and strengthening of the existing benefit-sharing policies for improvement of the livelihoods of the land beneficiaries. The nonexistence of the benefit-sharing mechanisms in the FBLR models remains an issue of concern that needs to be unequivocally addressed to ensure lateral and equitable beneficiation to all the beneficiaries.

\section{Acknowledgements}

The authors would like to extend the greatest words of appreciation to all the funding institutions, including the South African Forest Company Limited (SAFCOL) and National Research Foundation (NRF). In addition, we acknowledge the support that the Community Trust in Ama-Bomvini and the Community Property Association in Cata provided during our survey in their localities.

\section{References}

ANC (African National Congress). 2012. Land Reform Policy Document. Available at: http://www.anc.org.za/docs/pol/2012/landpolicyproposals_june2012v.pdf [accessed on 23 January 2017].

Anon 2017. DTI: Forestry and agro-processing sectors are key to growing the economy. Business Report, 04 October. Available at https://www.iol.co.za/business-report/dtiforestry-and-agro-prossesing-sectors-are-key-to-growing-the-economy11489419 [accessed on 28 February 2018]

Anseeuw W, Mathebula N. 2008. Evaluating land reform's contribution to South Africa's pro-poor growth pattern. South Africa's economic miracle-has the emperor lost his clothes? TIPS, Annual Forum.

Bhattacherjee A. 2012. Social science research: principles, methods, and practices. Textbooks Collection 3: University of South Florida.

Binswanger-Mkhize HP. 2014. From failure to success in South African land reform. African Journal of Agricultural and Resource Economics 9(4): 253-269.

Boynton PM, Wood GW, Greenhalgh T. 2004. Hands-on guide to questionnaire research: reaching beyond the white middle classes. BMJ: British Medical Journal 328(7453): 1433. 
Cairns RI. 2000. Outgrower timber schemes in KwaZulu-Natal-Do they build sustainable rural livelihoods and what interventions should be made? IIED \& CSIR.

Cernea MM. 2007. Financing for development benefit-sharing mechanisms in population resettlement. Economic and Political Weekly 42(12): 1033-1046.

Chirwa PW, Mamba S, Manda SM, Babalola FD. 2015. Assessment of settlement models for engagement of communities in forest land under claim in Jessievale and Roburna communities in Mpumalanga, South Africa. Land Use Policy Journal 46: 65-74.

Clarke J, Foy T. 1997. The role of the forest industry in rural development and land reform in South Africa, Commonwealth Forestry Review 76(3): 175-178.

Clarke J. 2007. Trends in forest ownership, forest resources tenure and institutional arrangements: Are they contributing to better forest management and poverty reduction? A case study from South Africa. Rome: FAO.

Collins D. 2003. Pretesting survey instruments: an overview of cognitive methods. Quality of Life Research 12(3): 229-238.

Cotula L, Leonard R. 2010. Alternatives to land acquisitions: agricultural investment and collaborative business models: Highlights from an international lesson-sharing workshop (Maputo, 17th-18th March 2010). IIED.

Cousins B. 2016. Why South Africa need fresh ideas to make land reform a reality. Poverty, Land and Agrarian Studies, University of the Western Cape.

Cundill G, Thondhlana G, Sisitka L, Shackleton S, Blore M. 2013. Land claims and the pursuit of co-management on four protected areas in South Africa. Land Use Policy 35:171-178.

Davis N, Lahiff E. 2011. Joint ventures in South Africa's land reform programme: strategic partnerships or strategic resource grab. In Global Land Grab conference, University of Sussex.

de Haen H, Thompson B. 2003. Food security in a world without borders. Forum Nutr 56: 375-379.

Deininger KW, May JD. 2000. Can there be growth with equity: An initial assessment of land reform in South Africa (Vol. 2451). World Bank Publications.

Dlomo M, Pitcher M. 2003. Changing ownership and management of state forest plantations: South Africa's experience. International conference on changing ownership and management of state forest plantations: issues, approaches, implications, Cape Town, South Africa, 6-8 November 2002. 
Forestry South Africa 2015. 14 ${ }^{\text {th }}$ Annual Report for the year ended $31^{\text {st }}$ of December 2015. http://www.forestry.co.za/uploads/File/industry_info/annual\%20Reports/FSA\%20Report \%202015.pdf [accessed on 15 March 2017].

Gwanya, T, 2010. Briefiing to the portfolio committee on rural development and land reform: The state of the community property association and other legal entities for land reform projects. Parliament, 3 March, Cape Town.

Hall R. 2004. A political economy of land reform in South Africa. Review of African Political Econom, 31(100): 213-227.

Hall R. 2011. Land grabbing in Southern Africa: the many faces of the investor rush. Review of African Political Economy, 38(128):193-214.

Hallam D. 2011. International investment in developing country agriculture: issues and challenges. Food Security 3(1): 91-98.

Kelley K, Clark B, Brown V, Sitzia J. 2003. Good practice in the conduct and reporting of survey research. International Journal for Quality in Health Care 15(3): 261-266.

Krejcie RV, Morgan DW. 1970. Determining sample size for research activities. Educational and Psychological Measurement 30(3): 607-610.

Lahiff E, Davis N, Manenzhe T. 2012. Joint ventures in agriculture: Lessons from land reform projects in South Africa. IIED/IFAD/FAO/PLAAS, London/Rome/Cape Town.

Lahiff E, Maluleke T, Manenzhe T, Wegerif M. 2008. Land redistribution and poverty reduction in South Africa. Research Report 36, Institute for Poverty, Land and Agrarian Studies (PLAAS), University of the Western Cape.

Lahiff E. 2007. Business Models in Land Reform. Institute for Poverty, Land and Agrarian Studies (PLAAS), University of the Western Cape.

Lahiff E. 2008. Land Reform in South Africa: A Status Report. Institute for Poverty, Land and Agrarian Studies (PLAAS), University of the Western Cape.

Mabece L. 2016. Forestry's industrial revolution has job-creation potential. Business Report, 01 August. Available at https://www.iol.co.za/business-report/opinion/forestrysindustrial-revolution-has-job-creation-potential-2051678 [accessed on 28 February 2018]

Mahanty S, Guernier J, Yasmi Y. 2009. A fair share? Sharing the benefits and costs of collaborative forest management. International Forestry Review 11(2): 268-280.

Makana C. 2012. Agri-SA warns of a timber industry decline. Sowetan, July, 31.

Makhathini M. 2010. Mondi "Sales and Leaseback" model in South Africa. In: Cotula L, Leonard, R (eds). Alternatives to land acquisitions: agricultural investment and 
collaborative business models: highlights from an international lesson-sharing workshop (Maputo, 17th-18th March 2010). IIED.

Mamba S. 2013. Evaluation of forestry models for future settlement of forestry plantations under land claims: The case of Jessievale and Roburna forest plantations in Mpumalanga, South Africa. MSc Theses, University of Pretoria.

Mathers N, Fox N, Hunn A. 2007. Surveys and Questionnaires. The NIHR RDS for the East Midlands/ Yokshire and the Humber. Available at https://www.rds-yh.nihr.ac.uk/wpcontent/uploads/2013/05/12_Surveys_and_Questionnaires_Revision_2009.pdf [accessed on 02 March 2018].

Mayers J, Vermeulen S. 2002. Company-community forestry partnerships: From raw deals to mutual gains? Instruments for sustainable private sector forestry series. International institute for Environment and Development, London.

Morsello C. 2006. Company-community non-timber forest product deals in the Brazilian Amazon: A review of opportunities and problems, Forest Policy and Economics 8(4): 485-494.

Mzinyane T. 2011. Commercial forestry faces range of challenges. Natural resources and the environment. CSIR.

National Planning Commission 2013. National development plan vision 2030.

Nawir AA, Santoso L. 2005. Mutually beneficial company-community partnerships in plantation development: emerging lessons from Indonesia. International Forestry Review 7(3): 177-92.

Nawir AA. 2012. Towards commercially oriented community forestry management: Coping with economic globalisation and commercialisation. In Conference proceedings: IUFRO 3.08. 00 Small-Scale Forestry Conference 2012: Science for Solutions, 24-27 September 2012, Amherst, Massachusetts USA.

Nemaangani MC. 2011. The implementation of the Public-Private Partnership model in land restitution claim settlement for the Masakona community in Limpopo Province, South Africa, Doctoral dissertation, University of Limpopo, Turfloop Campus.

Nyariki DM. 2009. Household data collection for socio-economic research in agriculture: Approaches and challenges in developing countries. Journal of Social Sciences 19(2): 9199.

Onwuegbuzie AJ, Collins KM. 2007. A typology of mixed methods sampling designs in social science research. The Qualitative Report 12(2): 281-316. 
Otsuka K. 2007. Efficiency and equity effects of land markets. Handbook of Agricultural Economics 3: 2671-2703.

Romano F, Reeb D. 2008. Understanding forest tenure in Africa: Opportunities and challenges for forest tenure diversification. Forestry Policy and Institutions Working Paper, Food and Agriculture Organization of the United Nations, Rome.

Sasu O. 2005. Decentralization of federal forestry systems in Ghana. In: Colfer CJP, Capistrano D (eds), The politics of decentralization: Forests, power and people. Earthscan/CIFOR. pp 196-211.

Sjetne IS, Bjertnaes OA, Olsen RV, Iversen HH, Bukholm G. 2011. The generic short patient experiences questionnaire (GS-PEQ): identification of core items from a survey in Norway. BMC Health Services Research 11(1): 88, doi:10.1186/1472-6963-11-88

Tilley S, Lahiff E. 2007. Bjatladi community restitution claim. Institute for Poverty, Land and Agrarian Studies (PLAAS), University of the Western Cape.

Van Loggerenberg C, Mandondo A. 2008. A study of outgrower Forestry in Southern Natal, exploring practice, perceptions, and prospects for SAPPI Project Grow.

Wong LP. 2008. Focus group discussion: a tool for health and medical research. Singapore Med J 49(3): 256-60. 